\title{
Peningkatan Apresiasi Sastra Melalui Teatrikal Puisi Bagi Siswa SMK Negeri 3 Banyumas
}

\author{
Erwita Nurdiyanto ${ }^{1}$, Gita Anggria Resticka ${ }^{* 2}$, \\ Nila Mega Marahayu ${ }^{3}$ \\ ${ }^{123}$ Universitas Jenderal Soedirman, \\ Purwokerto - Indonesia
}

\author{
Article Information \\ Submited April 06, 2021 \\ Revised Juni 07, 2021 \\ Accepted Juni 25, 2021 \\ Published Juli 22, 2021
}

\begin{abstract}
A language is a communication tool that can be done with spoken and written languages. Poetry is one example of fictionally expressed interactions. The poetry-forming element is the same as other literary genres. One form of literary appreciation is the reading of poetry with elements of musicality and iconicity that amazes. Literary appreciation is not a skill, but rather an art or tip that emphasizes aesthetics and literary awards. This community service activity is in collaboration with Banyumas SMK Negeri 3 school. Participants of this activity are students who have an interest in theater, especially extracurricular theater. The purpose of this devotional activity is to increase the literary appreciation of students of SMK Negeri 3 Banyumas through theatrical poetry. The benefits of this activity are expected that students can implement other theatrical poetry performances. Outside the activity in the form of theatrical staging is titled "Indonesia Tanah Air Mata". Outside of the devotional activities, students of SMK Negeri 3 Banyumas are expected to increase their creativity in appreciating literature contained in the form of performing arts

Keywords: Theatrical Poetry, Appreciation of Literature, SMK Negeri 3 Banyumas

Bahasa merupakan alat komunikasi yang dapat dilakukan dengan bahasa lisan dan bahasa tulis. Puisi merupakan salah satu contoh interaksi yang diungkapkan secara fiksi. Unsur pembentuk puisi sama dengan genre sastra lainnya. Salah satu bentuk apresiasi sastra yaitu pembacaan puisi dengan unsur musikalitas dan ikonisitas yang memukau. Apresiasi sastra bukanlah merupakan keterampilan, melainkan seni atau kiat yang menekankan estetika dan penghargaan sastra. Kegiatan pengabdian masyarakat ini bekerja sama dengan sekolah SMK Negeri 3 Banyumas. Peserta kegiatan ini adalah siswa-siswi yang memiliki minat terhadap teater, khususnya yaitu ekstrakurikuker teater. Tujuan diadakannya kegiatan pengabdian ini yaitu meningkatkan apresiasi sastra siswa SMK Negeri 3 Banyumas melalui teatrikal puisi. Manfaat dari diadakannya kegiatan ini diharapkan para siswa dapat mengimplementasikan pada pertunjukkan teatrikal puisi lainnya. Luaran kegiatan berupa pementasan teatrikal pusi berjudul "Indonesia Tanah Air Mata". Luaran dari kegiatan pengabdian diharapkan siswa SMK Negeri 3 Banyumas dapat meningkatkan kreativitasnya dalam mengapresiasi sastra yang tertuang dalam bentuk seni pertunjukkan.
\end{abstract}

Kata Kunci: Teatrikal Puisi, Apresiasi Sastra, SMK Negeri 3 Banyumas

*Korespondensi Penulis: Gita Anggria Resticka, gita.resticka@unsoed.ac.id, Fakultas Ilmu Budaya, Purwokerto, Provinsi 53122.

Copyright (C) 2021 Erwita Nurdiyanto, Gita Anggria Resticka, Nila Mega Marahayu, 


\section{Pendahuluan}

Bahasa adalah alat komunikasi yang dilakukan dalam 2 metode, yakni bahasa lisan dan bahasa tulis. Salah satu contoh interaksi dalam bahasa tulis yaitu dialog-dialog yang ada dalam naskah puisi dalam lingkup sastra (Adisaputera, Hadi, \& Hutagalung, 2020). Dalam tipe (genre) sastra, puisi ialah salah satu wujud pengungkapan sastra di samping tipe prosa atau drama. Puisi dibangun oleh unsur-unsur yang sama dengan genre sastra, khususnya fiksi (Dewojati, 2012). Namun, perihal yang perlu ditegaskan jika naskah drama tersebut ditulis untuk dipentaskan (Rendra, 2013). Berkaitan dengan hal tersebut, teks puisi tidak hanya pada konsep atau simbol kata verbal seperti novel. Akan tetapi, berisi konsep yang nampak (visual), terdengar (audible), dan terasakan (tangible) (Rohman, 2015).

Di dalam sastra, manusia dapat menemukan pengalaman-pengalaman kemanusiaan, imajinasi-imajinasi, dan sejenisnya untuk memenuhi hajat rohaninya sehari-hari. Sejalan dengan hal tersebut, dapat dikatakan bahwa sesungguhnya manusia tidak dapat dilepaskan atau terlepas dari sastra (Pradopo, 2012). Senantiasa manusia merasa perlu berinteraksi dengan sastra, meskipun kebutuhan ini menghadapi berbagai kendala sosial ekonomis dan persoalan lain. Tidak mengherankan bahwa masyarakat kita tumbuh subur dalam kegiatan-kegiatan yang berinteraksi dengan sastra. Hal ini bisa dilihat dalam tradisi mocopatan di Jawa, mabebasan di Bali, berbalas pantun di Sumatra, parikan di Jawa Timur, dan sebagainya. Selain itu, seringkali kita mendapati tulisan-tulisan berisi curahan hati seseorang yang tertuang dalam sebuah puisi. Menurut Saryono (2009), apresiasi sastra merupakan diagnosis mutu karya sastra dan pemberian nilai yang normal yang bersumber pada pengamatan serta pengamalan sadar serta kritis. Sejalan dengan pengertian tersebut, Kosasih (2008) juga menjelaskan bahwa apresiasi sastra yakni penghargaan (terhadap karya sastra) yang merupakan aktivitas internalisasi sastra. Dalam internalisasi sastra, jarak wajib dileburkan antara pembaca dengan karya sastra. Perihal ini berarti kalau aktivitas apresiasi sastra ialah sesuatu seni (kiat) yang menekankan estetika, penikmatan, serta penghargaan sastra. Perihal ini mengimplikasikan dalam apresiasi sastra berlangsung penerimaan seluruhnya karya sastra sehingga lebih menekankan keakraban antara pembaca serta karya sastra baik dalam membaca ataupun menulis kreatif (Kusumaningrum, Lendriyono, \& Prasetya, 2020), (Adisaputera, Lubis, \& Hutagalung, 2019).

Tidakhanyaitu, bentukaktivitas apresiasi sastra dapat dengan melisankan puisi tersebut secara ekspresif di dalam pementasan. Apresiasi sastra ialah internalisasi, subjektivitas yang jujur, luhur, mulia, serta individual tergantung pada pengapresiasinya (Kosasih, 2008). Dalam kegiatan pengabdian ini lebih ditekankan melalui kegiatan apresiasi sastra dengan melisankan puisi secara ekspresif. Jadi, dari naskah puisi yang kita maknai, kemudian dari pemaknaan itu baru diubah menjadi gerakan-gerakan atau teknik peran seperti dalam drama atau teater. Selanjutnya, kegiatan apresiasi sastra dengan puisi ini akan dipentaskan di atas panggung yang sering disebut dengan teatrikal puisi. Kegiatan pementasan ini akan dibagi menjadi kelompok-kelompok, dalam satu kelompok tersebut dapat terdiri dari sutradara, produser, aktor, dan tata pentas panggung 
yang meliputi tata kostum, panggung, musik, lampu, serta make up. Aktivitas apresiasi sastra ini bukanlah keterampilan, sebab keterampilan senantiasa mekanistik serta cara-caranya terkategori baku. Lebih tepatnya adanya apresiasi sastra sebetulnya bisa distatusi selaku seni ataupun kiat. Misalnya jika dicontohkan dengan pementasan teatrikal puisi, perwujudan aktivitas apresiasi sastra dapat beragam dari satu orang ke orang lain meski sastra yang diapresiasi sama. Teatrikal puisi merupakan salah satu alternatif bagi siswa dalam memahami serta mencintai atau mengapresiasi puisi karena unik dan begitu menyenangkan (Saryono, 2009). Dalam definisi teater atau drama dapat dibagi menjadi dua, yaitu drama sebagai hasil milik pribadi (repertoire) dan drama sebagai pertunjukan (theatre). Drama sebagai repertoire atau text play adalah hasil sastra milik pribadi, sedangkan drama sebagai theatre adalah seni kolektif atau pertunjukan (Rendra, 2013). Siswa akan mendapatkan manfaat, di antaranya mampu memahami atau manafsirkan karya sastra puisi serta mengambil nilai-nilai atau pesan moral dari bahasa puisiyang sulit, siswa dapatmengambil nilai-nilai tidak hanya dari keberhasilan dalam mengapresiasi dari naskah puisi ke dalam teatrikal puisi, tetapi juga nilai-nilai yang didapat dari proses produksi teatrikal puisi seperti kerja sama, bertanggung jawab, bekerja keras, dan mampu mengembangkan emosi yang sehat ke dalam kreativitas, dan sebagainya.

Dapat dikatakan bahwa adanya apresiasi sastra bukanlah sebagai sebuah keterampilan, melainkan sebagai kiat/ seni. Sebagai suatu kiat, apresiasi sastra tentulah mengandung unsur-unsur ilmu dan unsur-unsur keterampilan (Pradopo,
2009). Apresiasi sastra merupakan interaksi antara manusia dan sastra (Saryono, 2009). Untuk memperdalam ilmu apresiasi sastra, secara spontan yang dipelajari adalah dengan membaca buku-buku apresiasi sastra, sedangkan kiat yang harus diasah yaitu berbagai macam rencana latihan yang berkaitan dengan apresiasi sastra.

SMK Negeri 3 Banyumas merupakan salah satu institusi pendidikan yang memiliki sumber daya siswa dengan ketertarikan pada teater yang tinggi. SMK Negeri 3 Banyumas terletak di Jalan Gatot Subroto No. 1 Kecamatan Banyumas, Kabupaten Banyumas. SMK Negeri 3 Banyumas mempunyai empat jurusan antara lain yaitu seni tari, broadcasting, seni musik dan seni karawitan. SMK Negeri 3 Banyumas sebagai suatu institusi sekolah yang merupakan salah satu sekolah seni pertunjukan dengan siswa-siswa yang mempunyai apresiasi tinggi terhadap sastra ini dirasa perlu mendapatkan pelatihan mengenai peningkatan apresiasi sastra. Belum adanya wadah kreativitas dalam kegiatan apresiasi sastra menjadikan tim pengabdian tertarik melakukan sosialisasi serta praktik apresiasi sastra. Dalam hal ini, apresiasi sastra melalui teatrikal puisi. Teatrikal puisi merupakan pertunjukkan teater yang dibuat berdasarkan karya sastra puisi (Pradopo, 2012). Dalam tearikal puisi, puisi diperankan dalam pertunjukan teater dengan lebih menonjolkan estetika.

Sasaran pengabdian masyarakat adalah para siswa-siswa di SMK Negeri 3 Banyumas, kecamatan Banyumas, kabupaten Banyumas. Pengabdian masyarakat tersebut dilakukan karena tingkat apresiasi sastra siswa dalam seni pertunjukan di sekolah tersebut masih perlu ditingkatkan. Dalam pementasan teatrikal puisi, pemain mengekspresikan 
kreativitas dengan menerjemahkan aspek makna dalam tampilan lakon yang didukung oleh tata artistik. Kegiatan pengabdian ini akan memberikan kesempatan siswa untuk belajar mengapresiasi puisi melalui teknik teater atau drama teater yang biasa disebut teatrikal puisi dan dapat menjadi sarana dalam pembelajaran yang baik. Luaran yang didapatkan adalah Pementasan Teatrikal Puisi dengan tema "Indonesia Tanah Air Mata". Adanya luaran audiovisual tersebut dapat juga dijadikan sebagai bentuk promosi SMK Negeri 3 Banyumas terkait dengan kreativitas siswanya dalam pementasan teatrikal puisi, selain itu juga dapat dijadikan sebagai bentuk media promosi dalam penyaringan siswa baru.

\section{Metode Pelaksanaan}

Metode pelaksanaan kegiatan dalam program pengabdian masyarakat skema penerapan ilmu pengetahuan dan teknologi (Iptek) yang berjudul Peningkatan Apresiasi Sastra Melalui Teatrikal Puisi bagi Siswa SMK Negeri 3 Banyumas terdiri dari tahap perencanaan, tindakan, observasi dan evaluasi dan refleksi. Berikut tahapan-tahapannya :

\section{Perencanaan}

1. Koordinasi antara Tim Pelaksana Pengabdian skema Penerapan Iptek dengan SMK Negeri 3 Banyumas yang dimulai dengan mengundang tim pelaksana kemudian diberikan pembekalan mengenai maksud, tujuan, rancangan mekanisme program pengabdian skema penerapan iptek dan beberapa hal teknis berkaitan dengan metode atau teknik pelaksanaan.

2. Sosialisasi Program Pengabdian Masyarakat skema Penerapan Iptek di
SMK Negeri 3 Banyumas khususnya kepada siswa yang mengambil ekstrakurikuler teater.

3. Penyusunan kegiatan sosialisasi teatrikal puisi dengan terlebih dahulu telah mengidentifikasi, menganalisis permasalahan yang ada, dan menganalisis potensi sekolah, selanjutnya disusun program sosialisasi dan pendampingan teatrikal puisi.

\section{Tindakan}

Implementasi kegiatan ini berlangsung intensif selama dua bulan yang dibagi menjadi beberapa kali pertemuan. Kegiatan tersebut antara lain:

1. Memberikan teori puisi dan teater atau drama kepada siswa yang meliputi pemahaman dasar mengenai perbedaan antara membaca puisi, deklamasi puisi, musikalisasi puisi, dan teatrikal puisi; pemahaman tentang puisi meliputi definisi dan unsur-unsur pembangun puisi; pemahaman tentang drama atau teater meliputi definisi dan unsur-unsur drama dalam teknik pementasan.

2. Melakukan pelatihan dalam menginterpretasikan naskah puisi yang terbagi menjadi beberapa kelompok.

3. Melakukan pelatihan dalam bermain peran yang terbagi menjadi beberapa tahap antara lain pertama mendiskusikan bagaimana mengemukakan makna puisi ke dalam ucapan yang diatur dalam teknik membaca puisi secara tepat; siswa juga akan mengemukakan maksud dari naskah puisi ke dalam sebuah gerakan atau gestur.

4. Melakukan pendampingan kepada siswa dalam bermain peran hingga terlaksananya malam pementasan 
teatrikal puisi yang selanjutnya bertujuan untuk: mengasah keberanian siswa dalam mengukur dan mengeksplorasi kemampuan diri sebagai aktor; dan mengasah keberanian dan daya imajinasi maupun kreativitas siswa dalam memadukan tata pentas dalam mendukung pertunjukan teatrikal puisi.

\section{Observasi dan Evaluasi}

Masa observasi dan evaluasi dillaksanakan selama 2 bulan. Pada sesi akhir pendampingan, tim pengabdian memberikan kuesioner atau angket kepada siswa. Evaluasi ini menjadi tolok ukur apakah kegiatan ini berhasil atau tidak. Evaluasi berupa pre-test dan post-test untuk mengukur kemampuan siswa dalam bermain teater yang diadaptasikan dari sebuah puisi.

\section{Refleksi}

Untuk mengetahui kekurangan dan keberhasilan kegiatan dilakukanlah refleksi. Sehubungan dengan hal tersebut, terdapat nilai-nilai evaluasi yang dapat diambil dari kegiatan pementasan teatrikal puisi yaitu siswa dapat belajar percaya diri dan mengukur kemampuan diri dalam sebuah pementasan, bertanggung jawab dalam menyelesaikan tugas sebagai penyelenggara tontonan, baik bagi siswa yang bertugas sebagai aktor ataupun tata pentas, serta melatih kerja sama antarsiswa untuk menggarap sebuah pementasan dalam sebuah tim produksi atau tim pementasan teatrikal puisi. Selain itu, para siswa juga dapat mengambil nilai-nilai moral atau pesan yang terdapat dalam puisi yang dipentaskan.

\section{Hasil dan Pembahasan}

Dalam perencanaan kegiatan, dilakukan koordinasi antara tim pelaksana kegiatan pengabdian masyarakat dengan LPPM Universitas Jenderal Soedirman dan pihak SMK Negeri 3 Banyumas. Berdasarkan dari survei awal, didapatkan informasi bahwa di SMK Negeri 3 Banyumas tersebut teater hanya sebagai ekstrakurikuler yang hanya dilaksanakan setiap satu minggu sekali dan belum pernah mengadakan pementasan. Berdasarkan observasi dan hasil identifikasi dari sekolah mitra, kemudian melihat kebutuhan sekolah mitra serta hasil analisis potensi sekolah bahwa siswa-siswa di SMK Negeri 3 Banyumas mempunyai kompetensi di bidang seni, maka selanjutnya disusun program pelatihan. Setelah itu, melakukan perencanaan sosialisasi program pengabdian skema Masyarakat Penerapan Iptek pada SMK Negeri 3 Banyumas. Sosialisasi dilakukan antara tim pelaksana dengan sekolah mitra yaitu SMK Negeri 3 Banyumas. Pemberian materi sosialisasi ini berkaitan dengan teori teatrikal puisi dan teknik-teknik dalam pementasan.

Selanjutnya, tindakan pada kegiatan pengabdian ini berupa implementasi program yang telah direncanakan berdasarkan hasil survei dan diskusi tim pengabdian. Kegiatankegiatan yang dilakukan antara lain: Pertama, membahas materi pementasan yang terkait dengan pengetahuan dasar sastra, puisi, dan teknik pementasan drama (teatrikal). Materi mengenai pengetahuan dasar tentang sastra, puisi, dan drama (teatrikal) ini menjadi penting untuk dikaji demi tercapainya tujuan dalam memahami dan mengapresiasi sastra khususnya karya sastra puisi. Materi yang diberikan yaitu definisi puisi yang meliputi unsur-unsur pembangun puisi (bunyi, diksi, 
citraan atau imaji), dan cara memaknai puisi secara pembacaan heuristik maupun hermeneutik. Materi tersebut menjadi penting untuk memberikan pemahaman perbedaan karya sastra puisi dengan karya sastra prosa maupun drama. Dalam hal ini, puisi sebagai karya sastra dengan bahasa yang padat, berirama imajinatif. Dalam pemberian materi dan pemberian naskah teatrikal puisi diharapkan para siswa mampu memahami makna puisi secara eksplisit maupun implisit, sehingga mampu memberikan pemahamannya dalam bermain peran. Kedua, pemberian materi berupa definisi drama/ teater yang meliputi unsur-unsur drama/ teater dalam teknik pementasan. Unsurunsur pementasan drama di antaranya, yaitu naskah, pemain, sutradara, produser, tata rias dan busana, panggung, tata lampu dan musik serta penonton. Ketiga, tim pengabdian menentukan tema naskah yang akan dibuat dan dipentaskan, yaitu nasionalisme. Naskah teatrikal puisi tersebut merupakan naskah puisi jenis cento (kumpulan beberapa puisi) dari karya sastrawan Indonesia. Beberapa pusi tersebut sebagai berikut:

a) Puisi Berjudul "Aku Masih Sangat Hafal Nyanyian Itu" Karya Mustofa Bisri (Gus Muh) ;

b) Puisi Berjudul "Kau Ini Bagaimana atau Aku Harus Bagaimana” Karya Mustofa Bisri (Gus Muh)

c) Puisi Berjudul “Dor! Dor! Dor! Dor! Dor!” Karya Mustofa Bisri (Gus Muh)

d) Puisi Berjudul "Doa Orang Lapar" Karya Ws. Rendra

e) Puisi Berjudul "Selamat Pagi Indonesia" Karya Sapardi Djoko Damono

f) Puisi Berjudul "Rasanya Baru Kemarin" Karya Mustofa Bisri (Gus Muh).

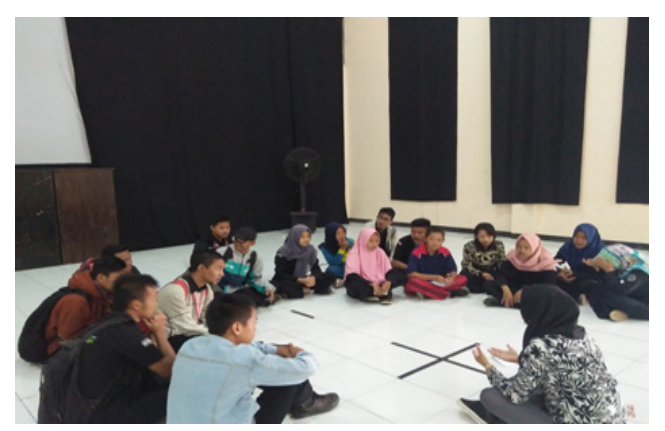

Gambar 1. Gladi bersih sebelum pementasan

Dalam pelaksanaan kegiatan, tim pengabdian masyarakat pun telah mengumpulkan data berupa beberapa puisi yang kemudian disusun menjadi sebuah naskah teatrikal puisi berjudul "Indonesia Tanah Air Mata". Tim pengabdian masyarakat dalam acara selanjutnya adalah memberikan latihan berupa pemahaman naskah. Pada tahap ini, siswa SMK Negeri 3 Banyumas telah ditugaskan untuk membaca dan memahami dahulu baru diadakan sesi diskusi. Hal ini dilakukan untk mengukur sejauh mana pemahaman para siswa terhadap naskah sekaligus sebagai bentuk adanya pemahaman dalam pembacaan heuristik dan hermeneutik, yaitu para siswa mampu memahami naskah teatrikal yang puitis tersebut dengan baik. Tim pengabdian dalam hal ini membantu mengarahkan dan memperdalam pemahaman terhadap makna atau nilai-nilai yang tekandung di dalam naskah, sehingga para siswa dapat memainkan perannya sebagai aktor dengan tepat, baik dalam dialog maupun gerak atau ekspresi. Begitu pula bagi para pemain musik, cahaya lampu, penata rias, juga mampu menyimak dengan baik karakter tokoh dan suasana atau setting sehingga mampu memberikan gambaran serta pemahaman dalam melakukan kreativitas dalam merias tokoh sesuai karakter yang diperankan, menentukan musik yang mendukung nilai rasa dari sebuah 
pementasan, serta menentukan cahaya atau lampu yang tepat untuk menyorot aktor di atas panggung pementasan.

Pada tahapan tersebut, tim pengabdian masyarakat telah membagi siswa berjumlah 40 tersebut ke dalam sebuah peran untuk mendukung para siswa dalam memahami dan totalitas dalam berteatrikal puisi, yaitu di antaranya membagi peran siswa sebagai sutarada, produser, sebagai tokoh maupun penari, penata lampu atau cahaya, penata rias dan busana, dan penata musik. Pembagian peran ini pun dilakukan dengan memberikan kebebasan dan keberanian para siswa untuk memilih peran mereka di dalam pementasan teatrikal tersebut. Dalam tahap ini, para siswa kemudian telah dipandu dalam membaca naskah teatrikal puisi tersebut bersama-sama. Tim pengabdian memberikan contoh pembacaan naskah dan dialog tokoh kemudian para siswa menyimak. Setelah tahap pembacaan naskah tersebut selesai, para siswa saling berlatih membaca naskah dan disesuaikan dengan perannya.

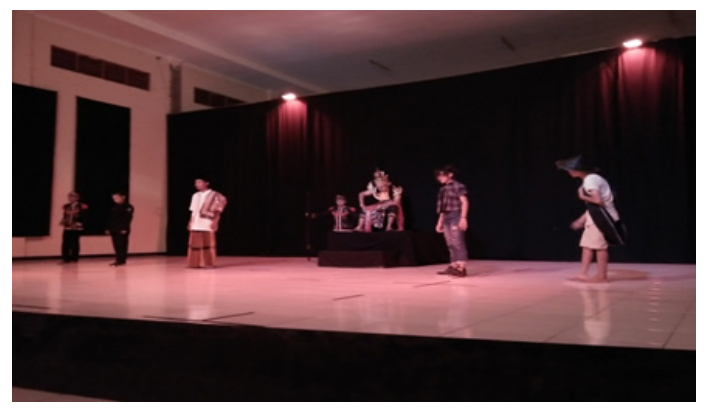

Gambar 2. Hasil dari konsep lighting dan tata panggung

Pembacaan dialog dalam naskah sesuai dengan peran para pemain antara lain:

a) Dialog dari tokoh Aku Liris sebagi pemeran utama

b) Dialog dari tokoh bayangan di Aku sebagai pemeran pembantu c) Dialog dari tokoh Raja sebagai pemeran pembantu

d) Dialog dari tokoh Rakyat yang terdiri atas petani, pelajar, preman, orang gila, kyai sebagai pemeran pembantu

e) Dialog dari tokoh Raksasa burung gagak yang terdiri atas tiga pemain sebagai pemeran pembantu

f) Latihan dalam menentukan getsture para pemain seperti pemain peran pengawal

g) Mendiskusikan hand prop pemain seperti tambang yang akan digunakan oleh pengawal saat membawa rakyat

h) Mendikusikan setting dan perabotan yang diperlukan di panggung pada saat pementasan

i) Menentukan keluar masuknya pemain sebelum berperan di panggung ; j) Mempelajari intonasi dan olah vokal para pemain agar maksud dari dialog tersampaikan maknanya pada penonton

j) Menentukan kostum para pemain dalam pementasan

k) Menentukan make-up untuk mendukung karakter para pemain dalam pementasan.

Selanjutnya, dalam tahap observasi dan evaluasi, sistem penilaian pada peserta terhadap materi diukur melalui komponen penilaian berupa penguasaan materi puisi, olah vokal, intonasi, gesture, hand property tim (kostum, musik), penguasaan tata panggung.

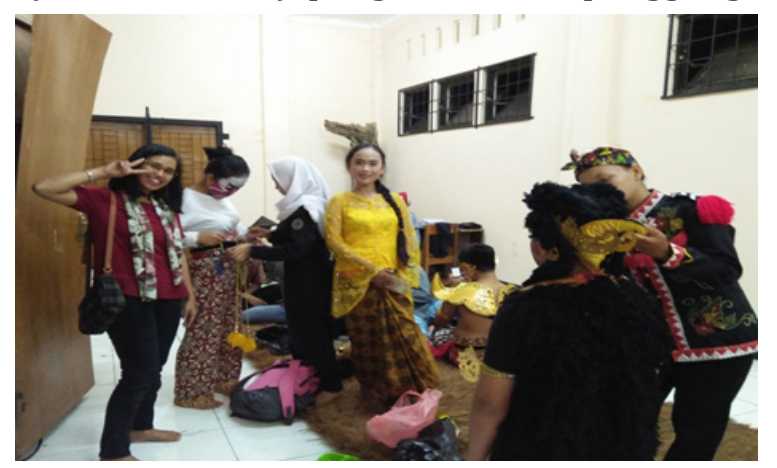

Gambar 3. Persiapan pementasan oleh penata rias dan busana kepada para pemain 
Kegiatan pengabdian masyarakat penerapan Ipteks ini secara garis besar meliputi: a) jumlah peserta yang melebihi target, b) tujuan pelatihan yang tercapai, c) ketercapaian materi yang dipahami siswa, d) kemampuan siswa dalam penerapan materi apresiasi sastra yang diberikan. Terdapat sebanyak tiga kali evaluasi yang akan dilaksanakan dalam kegiatan pengabdian ini, di antaranya adalah pelaksanaan tes awal sebagai evaluasi awal untuk mengukur pemahaman dan pengetahuan siswa-siswa SMK Negeri 3 Banyumas yang termasuk dalam salah satu kegiatan ekstrakurikuler. Selanjutnya kedua yaitu post-test. Post-test dalam kegiatan ini adalah persiapan untuk diadakannya pementasan teatrikal puisi. Adanya tes ini dijadikan sebagai tolok ukur efektivitas aplikasi dalam penyampaian materi mengenai apresiasi puisi yang telah dilakukan sebelumnya. Setelah tim pengabdian menentukan naskah puisi yang akan dijadikan sebagai naskah untuk pementasan. Selanjutnya adalah penentuan pemain dengan melakukan casting serta penentuan tim produksi yang meliputi tata rias, tata kostum, tata panggung/dekorasi, dan tata lampu. Berdasarkan hasil casting, kemudian dibuat kelompok-kelompok sesuai dengan seberapa banyak kebutuhan pemain dalam tiap naskah. Hal tersebut merupakan kegiatan pendampingan dan peninjauan langsung yang akan dilakukan oleh tim pengabdian.

Salah satu tujuan akhir kegiatan sosialisasi dan pendampingan mengenai teatrikal puisi yaitu terselenggaranya pementasan teatrikal puisi oleh siswasiswi SMK Negeri 3 Banyumas. Selanjutnya, evaluasi terakhir adalah evaluasi menyeluruh setelah diadakannya pementasan yaitu tim pengabdian memberikan selebaran mengenai pengisian kuesioner untuk mengetahui kekurangan dan kelebihan dari kegiatan pengabdian ini. Dari hasil evaluasi, diharapkan para siswa-siswa tersebut dapat lebih meningkatkan apresiasi sastra dalam hal teatrikal puisi dan kedepannya diharapkan dapat menyelenggarakan pementasan serupa dengan lebih baik. Pelaksanaan kegiatan pengajaran ini menggunakan metode diskusi grup. Dalam tahap ini, siswa akan dibagi menjadi beberapa kelompok dengan naskah puisi yang wajib. Hal ini sebagai langkah bagi para siswa untuk mengemukakan pendapat dalam interpretasi puisi serta menjadi media dalam mengeksplorasi kemampuan diri dalam bermain peran. Dengan metode ini, masalah atau kendala berupa interpretasi naskah puisi dan teknik bermain peran dalam sebuah teater atau drama yang dihadapi oleh siswa dapat dipecahkan. Tahapan dan cara di atas merupakan alternatif paling tepat untuk menggali dan mengembangkan bakat atau kemampuan siswa dalam bermain peran misalnya melalui teatrikal puisi.

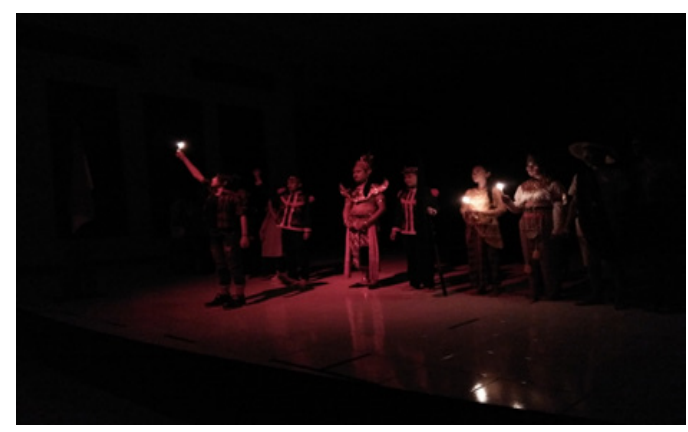

Gambar 4. Pementasan teatrikal dari naskah puisi jenis cento berjudul "Indonesia Tanah Air Mata"

Kegiatan pengabdian masyarakat penerapan Iptek pada akhirnya berjalan dengan sukses. Lancarnya kegiatan ini tidak terlepas dari semangat para siswa, guru pendamping serta pihak sekolah yang telah 
mendukung suksesnya acara pementasan teatrikal puisi. Berdasarkan hasil evaluasi dan hasil kegiatan, terdapat adanya faktor pendukung dan faktor penghambat pelaksanaan program pengabdian pada masyarakat penerapan Iptek ini. Faktor pendukungnya antara lain yaitu adanya kerja sama dari mitra yaitu pihak SMK Negeri 3 Banyumas yang sangat membantu dalam kesuksesan dan kelancaran kegiatan pengabdian masyarakat ini; keingintahuan dan antusiasme yang cukup besar dari para peserta pelatihan terhadap materi yang diberikan; ketersediaan sarana prasarana yang sangat mendukung dalam kegiatan pengabdian masyarakat ini. Selanjutnya, faktor penghambatnya adalah masih rendahnya tingkat pengetahuan peserta dalam menguasai materi mengenai apresiasi sastra melalui teatrikal puisi dan peserta pelatihannya yaitu para siswa-siswanya cenderung masih kurang fokus dalam sesi latihan misalnya pada saat latihan pembacaan naskah.

Teatrikal puisi ini merupakan bagian dari seni. Berbicara mengenai seni, terdapat beberapa konsep seni atau keindahan di dalam al-Qur'an. Keindahan di muka bumi ini digambarkan sebagai bukti dari kebesaran Allah SWT kepada umat-Nya. Sebagaimana Allah SWT berfirman:

“Wa huwallażì sakhkharal-bahra lita 'kulu minhu lahman tariyyaw wa tastakhriju minhu hilyatan talbasunahā, wa taral fulka mawākhira fihi wa litabtagu min fadlihī wa la'allakum tasykurụn" (QS. An-Nahl [16]: 14)

Artinya: dan Dia-lah, Allah yang menundukkan lautan (untukmu), agar kamu dapat memakan daripadanya daging yang segar (ikan), dan kamu mengeluarkan dari lautan itu perhiasan yang kamu pakai; dan kamu melihat bahtera berlayar padanya, dan supaya kamu men- cari (keuntungan) dari karunia-Nya, dan supaya kamu bersyukur (QS. An-Nahl [16]: 14).

Berdasarkan ayat di atas, bahwa alQur'an tidak menentang sesuatu yang memiliki nilai seni atau keindahan. Ayat tersebut menjelaskan bahwa laut diciptakan bukan hanya untuk sekedar menyediakan daging segar bagi manusia, tetapi juga perhiasan (mutiara) yang menunjang keindahan penampilan manusia.

Hasil kegiatan pengabdian maasyarakat ini bahwa puisi dapat ditransformasikan ke dalam berbagaikaryaseniabstrak dan konkret. Puisi memiliki kaidah seni. Ketika puisi itu disyairkan oleh penyairnya, terkadang isi dan makna puisi dapat mengungkapkan fenomena sosial di kehidupan manusia. Dalam karya konkret, puisi dapat berupa opera teatrikal dan pembacaan puisi itu sendiri oleh penyiar serta nyanyian dalam syair lagu.

\section{Kesimpulan}

Kegiatan pengabdian masyarakat penerapan Iptek dengan mitra SMK Negeri 3 Banyumas berjalan dengan baik, lancar dan sukses. Luaran kegiatan ini yaitu pementasan teatrikal puisi yang berjudul "Indonesia Tanah Air Mata". Para pemain dalam teatrikal puisi ini adalah siswa-siswa yang memiliki kompetensi dalam seni peran, kemudian diasah kembali dengan latihan-latihan rutin sehingga dapat menampilkan sebuah pementasan yang sangat mengagumkan. Luaran pementasan teatrikal puisi ini telah mampu meningkatkan kreativitas siswa dan telah memberikan kesempatan siswa untuk belajar mengapresisi puisi melalui teknik teater atau drama teater. Selain itu, luaran kegiatan ini juga dapat dijadikan sebagai 
sarana promosi bagi SMK Negeri 3 Banyumas.

Saran dari hasil kegiatan pengabdian masyarakat ini, yaitu SMK Negeri 3 Banyumas dapat mengimplementasikan dalam pementasan-pementasan lain dan dijadikan sebagai program rutin pementasan. Tim pengabdian yang terdiri dari dosendosen yang mempunyai kompetensi dalam bidang bahasa dan sastra harus terus aktif dan berinovasi untuk melakukan kegiatan pengabdian masyarakat dengan mitra lainnya baik yang berkaitan dengan peningkatan kreativitas dalam pementasan atau dengan peningkatan kompetensi yang lainnya.

\section{Ucapan Terima Kasih}

Ucapan terima kasih kami sampaikan kepada Universitas Jenderal Soedirman Purwokerto melalui LPPM yang telah memberikan dukungan dana dalam suksesnya program pengabdian ini. Kami sampaikan terima kasih dan apresiasi kepadaSMK Negeri 3 Banyumas yang telah berpartisipasi dalam kegiatan pengabdian masyarakat ini.

\section{Daftar Pustaka}

Adisaputera, A., Hadi, W., \& Hutagalung, T. (2020). Pembinaan Kemampuan Menulis Puisi Di Padepokan Iqro Desa Kolam Kecamatan Percut Sei Tuan Kabupaten Deli Serdang. Jurnal Pengabdian Kepada Masyarakat, 26(4), 175. https://doi. org/10.24114/jpkm.v26i4.19898

Adisaputera, A., Lubis, F., \& Hutagalung, T. (2019). Pembinaan Kemampuan Menulis Dongeng Bagi Guru Tk Aisyiyah 01 Kota Medan. Jurnal Pengabdian Kepada Masyarakat, 25(4), 223. https:// doi.org/10.24114/jpkm.v25i4.15119

Dewojati, C. (2012). Drama, Sejarah, Teori dan Penerapannya. Yogyakarta: Javakarsa Media.

Kosasih, E. (2008). Apresiasi Sastra Indonesia. In Jakarta : Nobel Edumedia.

Kusumaningrum, D. N., Lendriyono, F., \& Prasetya, D. M. (2020). Pelatihan Penulisan Esai Kreatif Bagi Pengembangan Bakat Sastra Anak Panti Muhammadiyah. Jurnal Pengabdian Kepada Masyarakat, 26(2), 90. https:// doi.org/10.24114/jpkm.v26i2.15220

Pradopo, R. D. (2009). Beberapa Teori Sastra, Metode kritik dan Penerapannya. Yogyakarta: Pustaka Pelajar.

Pradopo, R. D. (2012). Pengkajian Puisi. Yogayakarta: Gadjah Nada University Press.

Rendra, W. (2013). Seni Drama untuk Remaja. In Pustaka Jaya. Bandung.

Rohman, S. (2015). Teori dan Pengajaran Sastra. Jakarta: Rajawali Press.

Saryono, D. (2009). Dasar Apresiasi Sastra. Yogyakarta: Almatera Publishing. 